\title{
Ongoing IS Radical Ideology in Malaysia: Factors and Counter Strategies
}

\author{
Siti Zubaidah Abu Bakara ${ }^{*}$, Mohd Mizan Aslam ${ }^{\mathrm{b}}$ \\ aslamic Civilization Academy, Faculty of Social Sciences and Humanities, Universiti Teknologi Malaysia, 81310 UTM \\ Johor Bahru, Johor \\ ${ }^{b}$ School of Human Development and Techno-Communication, Universiti Malaysia Perlis, 01000 Kangar, Perlis \\ *Corresponding author: sitizubaidab@mmea.gov.my
}

\section{Article history}

Received: 2019-06-12 Received in revised form: 2019-06-24 Accepted: 2019-06-30 Published online: 2019-10-31

\begin{abstract}
Malaysia has long been recognized for its ability to manage threats from Islamic radical movements by overcoming significant obstacles and major challenges to national security. Although many movements have been banned and appropriate actions taken, Islamic radicalism nevertheless persists and appears on the rise. This study identifies factors associated with its persistence despite years of efforts to hinder or eradicate Islamic radicalism. Using qualitative historical sociology, the author used several resources for this analysis, including interviews and literature. Findings reveal four major factors that allow Salafi Jihadi ideology to prosper: a false reading of jihad, personal inclinations, political pressure, and globalization. Government actions countering this threat include declaring Malaysia an Islamic state; deradicalization and rehabilitation programs; national think tanks, prohibiting fatwas; introducing the concept of wasatiyyab; and implementation of counter narratives. Although the ideology cannot be completely eradicated, actions taken have managed to contain the contagion and also prevent major threats to national security.
\end{abstract}

Keywords: Ideology, National Security, Radical Islam, Salafi Jihadi, Takfiri 


\subsection{INTRODUCTION}

Thus far, the 21st century has shown dramatic growth in Islamic radicalism, not only in West Asia but also across East Asia and Europe. Daesh eclipsed Al Qaeda as the most feared movement and is known to have large numbers of supporters in SE Asia, including Malaysia. After initial arrests in 2013, the government confirmed that its main supporters include former members of Jemaah Islamiyah (JI) and Kumpulan Militan Malaysia (KMM).

JI was established in 1993 by former leaders of Darul Islam Indonesia (DII) who relocated and formed a new group in Malaysia. JI included members returned from the Afghanistan War who then funded and provided military training for new JI recruits as a result of cooperation with Al Qaeda and KMM, another Malaysian movement with veterans from the Afghan war against Russia in 1989. KMM sprung up two years after JI, in 1995, mostly comprising Malaysians who had gone to Pakistan as students and then entered the Russo-Afghan conflict. KMM member military experience was jointly employed by both groups, although each group had its own modus operandi for the realization of independent goals. The long-term plan for both groups was to form an Islamic region (Daulah Islamiyah) in SE Asia including Indonesia, Southern Philippines, Singapore, Malaysia and Southern Thailand. They believed the radical ideology of Salafi Jibadi would guide their success and thus collaborated. However, the 9/11 incident caused the Malaysian government to take concerted steps to detect and intervene all Islamic radical movements. Both groups were subsequently routed and banned.

This paper discusses current factors that affect sustained support for the Salafi Jibadi ideology in Malaysia, as well as steps taken by the government to halt this and similar ideological threats in the interest of national security, to include the aqidab of Muslims.

\subsection{METHODOLOGY}

This study's qualitative approach combines historical and sociological methods of data collection as the most appropriate approach to clarify phenomena drawn from a global Muslim society (Kuntowijoyo, 1993). A discursive route is taken through document analysis, interviews and literature to better clarify the increasing radicalism of Muslim militants (Kartodirdjo, 1992). Findings are arranged in chronological order and presented in narrative form to obtain a more comprehensive discussion.

\subsection{SALAFI JIHADI: A BRIEF OVERVIEW}

From $\sim 1970$ s to $\sim 1990$ s, Salafi Jihadi ideology was popularized during a global renaissance of Islamic revivalism (Dekmejian, 1995) and became an ideology of choice for radical movements (As-Suri, 2009: 30). The term emphasizes Salafiyah teachings introduced by Ibn Taimiyah and later revived by the Wahhabi movement. The term jihadi is representative of a concept called jihad qital by Sayyid Qutb (Sariburaja, 2013). Both terms were merged and reintroduced by Abdus Salam Faraj (As-Suri, 2009), a man who influenced many Muslim leaders, including Ayatollah Khomeini, Muammar Gaddafi, Saddam Hussein, Osama Ben Laden and Ayman Al Zawahiri (Esposito, 2010).

Salafi thought demands a return to the practice of Muslim scholars who lived during the first 300 after the death of Muhammad (Zulkarnain, 2017b). Its ideology forbids new changes in doctrine and demands that Muslims act as true believers by adhering to elements of al wala' wa al bara' - i.e., loyalty to Allah SWT (as One God) and by avoiding anything contrary to His law (alQahthani, 2013). They also adhere to Tawhid al-Hakimiyah, which is (i) obedience to Allah as the Page | 116 
only Owner/Author of Nature and Natural Law, and (ii) the struggle to make this specific approach to monotheism a tool that identifies enemies of Islam as either infidels or contrary Muslims (Azh-Zhawahiri, 2008). Jihad qital (war) is therefore permitted against 'contrary Muslims', specifically, any Muslim who fails to agree with this ideology. These are considered sufficiently infidel to legalize their murder.

At the dawn of the 21st century, takfiri became a label for Muslims who were ideologically aligned with Islamic radical movements, especially Daesh. The term Salafi Takfiri then replaced Salafi Jihadi and was initiated by Abu Muhammad Al Maqdisi, a man who rearranged Salafiyah teachings and Sayyid Qutb's definition of jibad (Syaikh Ali, 2015). The rebranding was then passed to Daesh by its founder, Abu Mus'ab Al Zarqawi (Wagemakers, 2012). This group adheres to the idea of takfiri labelling of infidels, as a modified Sayyid Qutb position, whose jihad qital was to be applied, not only to opponents who qualify as infidels but also to any and all administrative and government systems that do not admit Tawbid al-Hakimiyah. Such governments are called taghut (Bakashmar, 2008). Hence, Muslims other than the new cult's supporters became infidels, whereupon principles of jihad required their blood as well as that of ordinary non-Muslim infidels.

In Malaysia, this radical ideology evolved by way of dakwah (Maszlee, 2017; Mohd Roslan \& Wan Mohd Tarmizi, 2011). From pre-independence days, Islamic radical movements were highly influenced by West Asian figures such as Jamaludin Al Afghani, Muhammad Abduh, Sayyid Abu A'la Al Mawdudi, Hassan Al Banna, and Sayyid Qutb (Kamarulnizam, 2003). This ideological set became deeply rooted in educational venues and likely reflects influence from students returned from abroad as civil servants, in addition to improved public education systems and the madrasah system; not to mention preachers and traders who regularly visit SE Asia (Suffian, 2010). Presently, radical ideology survives and even thrives in increasingly diverse and complex ways.

\subsection{COMPETITIVE FACTORS AFFECTING THE SPREAD OF ISLAMIC RADICAL IDEOLOGY IN MALAYSIA}

Our discussion on competitiveness between JI, KMM and Daesh has been combined due to their shared dynamics and means. Four major factors influence the survival of Islamic radical ideology in Malaysia. The first concerns jihadi parallels; the second, political pressure; the third, individual inclinations; the fourth, globalization.

\subsection{The Jihadi Struggle}

The most significant factor leading to direct or indirect participation by Malaysians is attraction to the radical ideology of jihad (Samuel, 2016; Ahmad, 2016; Muhamad Sade, 2016; Ayob Khan, 2016; Mohd Mizan et al., 2016; Wan Mohd Zaki, 2015). Differences between terms-Salafi Jibadi per JI and KMM, and Salafi Takfiri per Daesh supporters-are not a problem (Zulkarnain and Nordin, 2013; Mohd Mizan, 2009a) because the ideological struggle is the same for all groups (Ramakrishna, 2016). They believe jihad is fardhu ain (Ahmad, 2016) because the need for jihad has been mentioned for more than forty times in Al-Qur'an. Hence, it is powerful motivation, especially martyrdom's promise of immediate admission to heaven (Hanif, 2015).

Nonetheless, the concept of jihad has been grossly misconstrued and horribly reconstructed by these radical movements (Hamzah, 2017; Mohd Basri, 2016; Kamaruzaman et al., 2010b). This followed the integration of Salafiyah elements regarding jihad as demanded by Shari'ah (Wan Mohd Zaki, 2015; Kamarulnizam \& Mohd Affandi, 2015); a handful of people who sought out religious teachers to boost its support (Abdul Aziz, 2009). These doctrinal innovations were introduced to 
ustaz and kiyai of much influence and high credibility, who then conveyed and even endorsed the radical thinking (Kamarulnizam, 2009). Moreover, radical groups are very genial, supportive and accommodating. They establish tight-knit communities (IYRES, 2017) and alluringly encourage participation. Most recruits are influenced by subtle doctrines (propaganda) and the lure of martyrdom's rewards (Mohd Hizam \& Zamihan, 2016; JPM, 2014). Couple this with the fact that many Muslims seek true Islam in lieu of predominantly corrupt governance, such persuasiveness purchased ongoing support (Mohd Mizan, 2009b).

\subsection{Political Pressure}

Many radicals consider Malaysia taghut because its government does not fully implement Shari'ah (Ayob Khan, 2016; Ahmad, 2016; Samuel, 2016; Muhamad Sade, 2016; Mohd Mizan, 2009a; IYRES 2017; Zulkarnain, 2017a; Kamarulnizam, 2009). They therefore doubt the government's ability and desire to manage Malaysia as an Islamic state (Kamaruzaman. et al., 2010b) especially because current praxis does not draw on concepts of al wala' wa al bara' (Abdul Aziz, 2009). To complicate matters, Malay rulers hold critical differences on matters concerning modernization and also appear to tolerate secularism and generic attacks by globalists on religious values associated with governance (Zulkarnain, 2014).

Radicals argue the Malaysian government has failed to formulate clear Islamic policies that implement Islamic governance, which, in turn, has encouraged the dominion of Western ideology since independence (Kamaruzaman, et al., 2010a). Malaysia's position is certainly contrary to "Islamic rule" as supposedly practiced by Daesh (Mohd Hizam \& Zamihan, 2016). Consequently, radicals feel obliged to militantly rise in jibad and establish their brand of Daulah Islamiyah (JPM, 2014; Wan Abdul Hamid, 2006; Nasir, 2006; IYRES, 2017).

\subsection{Personal Inclinations}

Personal inclinations are influenced by individuals, families and social conditions. The most critical of these several factors include the following: loneliness, failure to achieve personal ambitions, inability to marry, a sense of inferiority, and not being appreciated by the community (Ahmad, 2017; Hanif, 2015). Depression due to a lack of support causes a kind of self-exile (Kamaruzaman, et al., 2010b; Abdul Aziz, 2009). Personal and social disappointments thus open doors for radical movement recruiters (Zulkarnain, 2017a). Some join radical movements out of a fragile sense of self-esteem and profound ignorance. They entertain extremist positions (Samuel, 2016) in a kind of delirium that subconsciously accepts violence and terrorism as rational (Wan Mohd Zaki, 2015), and with deep sympathy for the fate of Muslims persecuted by the West (Ahmad, 2017; Samuel, 2016; Hanif, 2015).

Family influences are no less important (Mohd Mizan, et al., 2016). Some are influenced by family members who struggled against past occupation (Respondent A1, 2017). Others admit they feel neglected by their families or were raised in dysfunctional households (Ahmad, 2017). Some are victims of divorce with issues regarding child custody (Mohd Basri, 2016). Others come from reclusive families that failed to mingle with the community at large; thus causing constricted, narrow-minded home environments (Kamarulnizam, 2009). Economic status is also a contributing factor (Samuel, 2016; Bakashmar, 2008). Those from poor families are more susceptible to promises of rewards when joining radical groups (Mohd Hizam \& Zamihan, 2016).

Social factors and milieus adversely affected by modernization can cause communal turmoil (Mohd Mizan, et al., 2016; Zulkarnain, 2014). These, along with peer pressure, significantly 
influence recruits to radicalism (Hanif, 2015; Kamaruzaman, et al., 2010b). On their own initiative, some individual recruit students who studied in Pakistan and became involved in the Afghanistan war (Respondent A2, 2016). Such individuals lead many others to support the idea of establishing Daulab Islamiyah (Nasir, 2011; Mohd Mizan, 2009a). Malaysia's relations with West Asian countries, particularly in educational sectors, have allowed a small number of students to access military training and enter the Afghan conflict, after which they return home, hot with ideology and military skills (Mohd Mizan, 2009b). This element goes far to inspire local support for radicalism.

\subsection{Globalization}

Globalization implies technological sophistication, demographic changes, population growth, and degrees of international economic and political continuity. Radical Islamic movements have grown in parallel. Globalization allows Malaysians access to detailed international developments. Many observers and political analysts say that radical movements of the new millennium focus on religious motivation (Zulkarnain and Lailatul, 2016) because Muslims are globally oppressed (IYRES, 2017; Zulkarnain and Nordin, 2013) and with no end in sight (Samuel, 2016). Thus, sympathy with conflicts in West Asia (Hanif, 2015) creates solidarity in Malaysian Muslim communities based on ukhuwah Islamiyah (Ahmad, 2016). Thereby, local supporters of radicalism feel responsible to defend the global Muslim ummah.

In addition, online social media especially permits recruiters easy access to naïve youth (Mohd Mizan et al., 2016). Radical ideology disseminates via blogs, Facebook, Surespot, Twitter, Instagram, Telegram and Skype, and is far more difficult to detect and track compared to the old modus operandi of organized usrahs (Ayob Khan, 2016). Propaganda masters have developed new coding and various applications to upload songs and videos on Youtube that promote their strength while encouraging new recruits to migrate to Islamic State of Daesh (Mohd Hizam \& Zamihan, 2016). They influence people who do not understand regional or international politics. Globalization via the internet, has easily and effectively obtained the support of many unwary Muslims.

\subsection{MALAYSIA'S RESPONSES TO THE THREAT OF RADICAL IDEOLOGY}

The Malaysian government has taken a number of integrated measures to counter radical ideological threats. These include declaring Malaysia an Islamic state; programs for the rehabilitation of detainees; national think tanks; an official fatwa proclamation; the promotion of Islamic $W$ asatiyyab; and the dissemination of counter narratives.

\subsection{Declaring Malaysia An Islamic State}

In the wake of 9/11, Prime Minister Tun Dr Mahathir Mohamad declared Malaysia an Islamic state, specifically to emphasize the government's position on the irrelevance of establishing an Islamic state, which is the stated jihadi goal of radical movements, especially JI and KMM (Mohd Mizan, 2009b; Mahathir, 2002). He also slammed the labelling of Islam a 'religion of violence' because terrorism exists regardless of religion, race or belief system. Hence, blaming Islam for terrorism was a grave injustice (Abdul Rashid, 2003). Nonetheless, the government also believed that a lack of systemic Islamic praxis caused the nation's radicals to feel stressed and even oppressed. To ease this tension, perceived and not, the government provided better ways to 
implement Islamic policies (Abuza, 2003). These actions aimed to preemptively reduce antagonism, stressors, radical demands and subsequent acts of terrorism (Mahathir, 2001).

\subsection{Rehabilitation Program Content}

Government-initiated rehabilitation and deradicalization programs for radical detainees attempt to neutralize dangerous ideology. These are implemented by the Royal Malaysian Police (PDRM) in collaboration with the Prime Minister's Department (JPM), the Department of Islamic Development Malaysia (JAKIM), and other experts including experienced counselors and academicians. JI and KMM detainees are examined regarding general knowledge of Islam, jibad and views on an Islamic State. A series of corrective talks, classes and Tafaqqub Fiddin are then conducted (Rabasa et al., 2010). Critical issues such as aqidah, the Islamic state, democracy, obedience to leaders, jihad, Islam and the matter of infidels are discussed. Understanding the Qur'an and methods of jitihad and mursalib mursalah as well as state priorities and strategic thinking are introduced and discussed so detainees come to a better understanding of authentic Islam that readjusts their perspectives.

Periodically, Daesh detainees are required to review these same modules to focus on selfreflection, discipline, affection, management and social survival skills. PDRM and Ministry of Home Affairs $(\mathrm{KDN})$ programs collaborate in the use of select former radicals who share experience and ideas with detainees (Ahmad, 2017, Mohd Mizan, 2009a).

\subsection{Think Tanks}

To ensure the country remains informed of current local and international radical machinations, several think tanks were created to gather data, conduct research, and recommend proactive actions. These groups deal not only with ideological threats but also with actual attacks. They include the Southeast Asian Regional Center for Counter-Terrorism (SEARCCT, 2016) in Kuala Lumpur, organized by the Ministry of Foreign Affairs (KLN) to provide structured training by experts who also share investigative results on regional violence (KLN, 2018). Another is the Institute for Youth Research Malaysia (IYRES) under the Ministry of Youth and Sports, which studies the progress and development of the nation's youth. They direct programs that define theological and political errors in radical ideology, specifically to eradicate misconceptions and manage imminent matters of importance (KBS, 2018).

The Institut Pemantapan dan Pengkaderan Akidah Malaysia (IPHAM), under JAKIM, implements various programs and activities for those who offend aqidah based on judicial judgments. This group specifically seeks to build public awareness while assisting state measures to contain and overcome the manipulation of aqidah.

\subsection{Fatwa Proclamation to Ban Daesh}

The ideological threat posed by Daesh developed rapidly and quietly, primarily through social media. Malaysia's Fatwa Muzakarah National Committee, under JAKIM, issued a fatwa ruling that banned any and all Daesh-style jihad activities due to extremist positions considered contrary to Abli Sunnah Wal Jamaah (ASWJ), Malaysia's official Islamic school of thought. The committee also declared that the death of anyone who partook in Daesh's struggle did not qualify as martyrdom (JAKIM, 2015; Norliah, 2016). Contradictory elements of Daesh-stye jih ad include cruel murder methods, mass oppression and the upholding of Khilafah Islamiyah through qital jihad. Prohibited 
acts include belief-in and spreading Daesh ideology, funding Daesh, and pledging loyalty to Daesh authorities (Mufti Selangor, 2018).

The government's fatwa aligns with world scholars like Abdul Aziz al-Sheikh (a Saudi Mufti); Sheikh Yusuf al-Qaradhawi (Chairman of World Islamic Scholars); and Sheikh Shawqi Allam, the Egyptian Grand Mufti who condemned Daesh as violators of Islam and Shari'ab (JPM, 2016).

\subsection{Promoting Wasatiyyah Islam}

The government's best solution is the concept of wasatiyyah which promotes Islam as a moderate religion. Hence, clarification is given to all levels of the Muslim community giving each individual ample reason to reject radical ideology. The concept of wasatiyyah corrects general perceptions of Islam by addressing the unwarranted but nevertheless rising global fear of Muslims (Islamophobia) (Noh, 2018).

The government's sincerity manifest as the Malaysian Wasatiyah Institute (IWM, Dec. 2012), an institution that promotes Islam as moderate, balanced, fair and admirable. In parallel, a National Wasatiyyah Policy was enacted to clarify the government's intent to promote this understanding as national Muslim praxis in a concerted effort to overcome extremism in the community (IWM, 2017).

\subsection{Implementing A Counter Narrative}

The government recognized that ideological attacks by radical movements, particularly Daesh, required the propagation of a counter narrative. Accordingly, under PDRM, the government set up a Regional Digital Counter-Messaging Center (CMC) in 2016 to implement a counter narrative containing select ideological matters (NST, 2018; Muhamad Sade, 2016). Data received is analyzed and directly channeled to Interpol and Aseanpol. Measures are then taken to correct misconceptions of Islam and which emphasize the government's position of wasatiyah. These messages are specially channeled through social media, the preferred method of choice by Daesh members (NST, 2016).

The Malaysian Armed Forces (ATM) participate in this counter narrative. Some misunderstandings, such as jihad as fardhu ain, for example, have no other meaning than war in the mind of radicals. Another is migration as an obligation, meaning Muslims are obliged to complete their faith by relocating to an Islamic state, especially the Daesh state. Another is Daesh's description of their caliphate as the utopian model of a glorious Islamic state; one emulating that of the Prophet's time (Zulkarnain, 2017b). Radicals also teach that Syria and Iraq are the most suitable venues for jïhad.

Additionally, the Counter Narrative Centre for Countering Violent Ekstremisme (CONCAVE-ISSI) announced academic fellowship appointments in March 2018, specifically to oppose extremism with academic narratives on authentic Islamic thought and tradition. To further a stable flow of knowledge and sense of security in the community, CONCAVE-ISSI raises public awareness by conducting forums, symposia, seminars and course work. The Malaysian Communications and Multimedia Commission (MCMC) meanwhile monitors and blocks access to websites promoting sensitive or inappropriate content that ideologically break with authentic Islam and also threaten Malaysia (Ahmad Zahid, 2016). This strict supervisory control (censorship) is also carried out regionally in a cooperative effort with other countries. 


\subsection{National Expert Rehabilitation Panel}

In addition to Prevention of Terrorism Act 2015 (POTA) and Security Offences (Special Mesures) Act 2012 (SOSMA), the KDN launched a National Expert Rehabilitation or Deradicalization Panel on 30 March 2017. This group collaborates with government agencies such as PDRM, the Prison Department (Penjara), JAKIM, and the Ministry of Education (MOE).

Its experts come from various disciplines including psychologists, security personnel, academicians, social workers and entrepreneurial experts; some with extensive experience handling radical detainees from JI and KMM. Additional collaboration between Penjara and PDRM was strengthened when the orginal six experts on the panel grew from 5 or 6 to a current level between 40 to 50 members (Gunaratna, 2018). Modules conducted by the panel have structurally increased and now include vocational training, educational programs, social and family counselling, as well as recreational, psychological, creative arts and financial rehabilitation (Ahmad, 2017).

\subsection{CONCLUSION}

According to government reports, by 2011, 95\% of 240 detainees, mostly from JI and KMM, had been fully deradicalized. The remaining $5 \%$ have since been categorized as hard-core radicals who would readily re-engage with Al Qaeda and Daesh (Mohamad Fuzi, 2016). Another writer reports that from 2013 to 2017 the number of detainees increased from 4 to 95. The highest numbers of arrests (292) were made in 2016 due to the conflict in Aleppo, which directly caused Malaysian militants to join Daesh (Mohd Mizan, 2018).

Various factors have been identified as that sustain Islamic radical ideology and its recruits. Salafi Jibadi and Salafi Takfiri ideations commonly unite radical supporters with the goal of establishing a Khilafah Islamiyah. Research findings show that despite a range of concerted counter measures taken by the government, ideological belief systems are uniquely individual and cannot be measured objectively. Hence, efforts to raise awareness and inform society must be consistently maintained to ensure containment of risk and the reduction of threats to national security.

\section{List of Reference}

Abdul Aziz Hussin. (2009). Salafiyah Jihadiyah Dan Keganasan Politik: Kajian terhadap Jemaah Islamiyah (JI), Master Thesis, Fakulti Sains Sosial dan Kemanusiaan, Universiti Kebangsaan Malaysia, Bangi.

Abdul Rashid Raja Badiozaman. (2003). "Foreward." In Terrorism And The Real Issues, edited by Mohamad Mahathir. Selangor, Pelanduk Publications Sdn Bhd.

Abuza, Z. (2003). Militant Islam in Southeast Asia, Crucible Of Terror. London: Lynne Rienner Publishers.

Ahmad El-Muhammady. (2016). "Countering the threats of Daesh in Malaysia." Panorama: Insights into Asian and European Affairs no. 02/2016, 105-122.

Ahmad El-Muhammady. (2017). Ancaman radikal Islam di Malaysia. Interviewed by Siti Zubaidah, Abu Bakar. Jan 21, 2017.

Ahmad Zahid Hamidi. (2016). "Malaysia's policy On Counter Terrorism And Deradicalisation Strategy." Journal of Public Security and Safety, 6(2), 1-19.

As-Suri, A.M. (2009). Perjalanan gerakan Jihad (1930-2002): Sejarah, eksperimen Dan Evaluasi. Translated by Agus Suwandi. Solo, Jazera.

Ayob Khan Mydin Pitchay. (2016). Ancaman radikal Islam Di Malaysia. Interviewed by Siti Zubaidah Abu Bakar. May, 18.

Page $\mid 122$ 
Azh-Zhawahiri, A. (2008). Dari rahim Ikhwanul Muslimin ke pangkuan Al Qaida. Translated by Mush'ab Umar Burhanuddin. Klaten Jateng, Indonesia: Kafayeh.

Badlihisham Mohd Nasir. (2011). "The influence of Middle East Islamic Movement on the extremist thought in Malaysia." Tawarikb: Iternational Journal for Historical Studies, 3(1), 31-46.

Bakashmar, M. (2008). "Winning the Battles, Losing the War? An Assessment of Counterterrorism in Malaysia." Terrorism and Political Violence, 20, 480-497. https://doi.org/10.1080/09546550802257200

Dekmejian, R. H. (1995). Islam in revolution Fundamentalism in the Arab World. 2nd ed. New York, Syracuse University Press.

Esposito, J.L. (2010). The future of Islam. New York, Oxford University Press.

Gunaratna, R. (2018). Terrorist Rehabilitation And Community Engagement in Southeast Asia. edited by RSIS. Singapore.

Hamzah Ishak. (2017). Ancaman Radikal Islam di Malaysia. Interviewed by Siti Zubaidah Abu Bakar. Feb, 14.

Hanif Yusabra. (2015). Islamic State (IS) implikasi Kepada Keselamatan Negara, Master Thesis, Fakulti Sains Sosial dan Kemanusiaan, Universiti Kebangsaan Malaysia, Bangi.

IWM. (2017). Dasar Wasatiyyah Negara. Putrajaya: Penerbit Insitut Wasatiyyah Malaysia.

IYRES. (2017). Garis Panduan Pencegaban Fahaman Ekstremisme dan Radikalisme Dalam Kalangan Belia dan Masyarakat. edited by Kementerian Belia dan Sukan. Putrajaya, Institut Penyelidikan Pembangunan Belia Malaysia.

JPM. (2014). Kertas Putib: Ke arah menangani ancaman kumpulan Islamic State. edited by Jabatan Perdana Menteri. Putrajaya, Kerajaan Malaysia.

Kamarulnizam Abdullah. (2003). The politics of Islam in contemporary Malaysia. Bangi, Penerbit Universiti Kebangsaan Malaysia.

Kamarulnizam Abdullah. (2009). "Kumpulan Mujahidin Malaysia (KMM) and Jemaah Islamiyah (JI): The links." Journal of Policing, Intelligence and Counter Terrorism, 4(1), 1-33. https://doi.org/10.1080/18335300.2009.9686922

Kamarulnizam Abdullah., \& Mohd Afandi Salleh. (2015). "Conceptualizing jihad among Southeast Asia's Radical Salafi movements." Journal for The Study of Religions and Ideologies, 14(42), 5

Kamaruzaman Yusoff, Iran Herman \& Badlihisham Mohd Nasir. (2010a). "Islamic radicalism in Malaysia: An overview." Procedia Social and Behavioral Sciences, 5, 2326-2331. https://doi.org/10.1016/j.sbspro.2010.07.458

Kamaruzaman Yusoff, Iran Herman \& Badlihisham Mohd Nasir. (2010b). "Islamic radicalism in Malaysia: Gender perspective." Procedia Social and Behavioral Sciences, 5, 2129-2225. https://doi.org/10.1016/j.sbspro.2010.07.424

Kartodirdjo, S. (1992). Pendekatan Imu Sosial Dalam Metodologi Sejarah. Jakarta: Gramedia Pustaka Utama.

KBS. (2018). Latar Belakang IYRES. Retrieved on 9 July 2018, from https://www.iyres.gov.my/index.php/ms/profil/mengenai-kami

KLN. (2018). About SEARCCT- Introduction. Ministry of Foreign Affairs Malaysia 2018. Retrieved on 7 December 2018, from https://www.searcct.gov.my/about-searcct/introduction

Kuntowijoyo. (1993). Paradigma Islam: Interpretasi untuk aksi. Bandung, Penerbit Mizan.

Mahathir Mohamad. (2001). "The need to identify terrorists and remove the causes of terrorism." In Terrorism and the real issues, edited by Mohamad Mahathir. Selangor, Pelanduk Publications Sdn Bhd. 
Mahathir Mohamad. (2002). "Malaysia has No Tolerence For Terrorists." In Terrorism And The Real Issues, edited by Mohamad Mahathir. Selangor, Pelanduk Publications Sdn Bhd.

Maszlee Malik. (2017). "Salafism in Malaysia: Historical Account On Its Emergence And Motivations." Sociology of Islam, 5, 303-333.

Mohamad Fuzi Harun. (2016). Malaysia's experience On Deradicalization And Rehabilitation Paper read at International Conference on Deradicalisation and Countering Violent Extremism 2016, at Grand Hyatt, Kuala Lumpur.

Mohd Basri Ibrahim. (2016). "Faktor Kemunculan Militan Islam Dalam Masyarakat." In IS/ ISIL/ Daesh/ ISIS, edited by Maszlee Malik. Selangor, PTS Publications and Distributors.

Mohd Hizam Hanafiah, \& Zamihan Mat Zin. (2016). Bahaya ISIS (Daesh). Negeri Sembilan, Al Himna Enterprise.

Mohd Mizan Aslam. (2009a). A Critical Study Of Kumpulan Militan Malaysia, Its Wider Connections In The Region And The Mplications Of Radical Islam For The Stabilitiy of South East Asia, PhD Thesis, Public Policy, Victoria University of Wellington, New Zealand.

Mohd Mizan Aslam. (2009b). "The thirteen Radical Groups: Preliminary Research In Understanding The Evolution Of Militancy in Malaysia." JATI-Journal of Southeast Asian Studies, 14, 145-161.

Mohd Mizan Aslam. (2018). The Threat of DAESH in Malaysian Higher Education Institutions. In MyRISS Special Report to Ministry of Higher Education Malaysia. Kuala Lumpur.

Mohd Mizan Mohd Aslam, Iffah Bazilah Othman, \& Nur Aqilah Khadijah Rosli. (2016). "De-radicalization programs in South-East Asia: A comparative study of rehabilitation programs in Malaysia, Thailand, Indonesia and Singapore." Journal of Education and Social Sciences, 4, 154-160.

Mohd Roslan Mohd Nor, \& Wan Mohd Tarmizi Wan Othman. (2011). "Sejarah dan perkembangan Pendidikan Islam di Malaysia." Jurnal At-Ta'dib no. 6(1). DOI: 10.21111/at-tadib.v6i1.547

Mufti Selangor. (2018). Fatwa Gerakan Militan Al-Dawla Al-Islamiya Fi Iraq Wa Al-Sham (Daesh), Atau Militan Islamic State In Iraq And Syams (ISIS), Atau Islamic State Of Iraq And The Levant (ISIL) Atau Militan Islamic State (IS). $\quad$ Retrieved on 12 July 2018, from http://www.muftiselangor.gov.my/images/pdf/koleksi_fatwa/2016/Fatwa\%20Militan\%20AlDawla _IS.pdf

Muhamad Sade Mohamad Amin. (2016). Ancaman radikal Islam Di Malaysia. Interviewed by Siti Zubaidah Abu Bakar, Nov. 21.

Nasir Abas. (2006). Membongkar Jamaah Islamiyab: Pengakuan Mantan Anggota JI. Jakarta, Penerbit Grafindo Khazanah Ilmu.

Norliah Sajuri. (2016). Malaysia's experience on deradicalization and rehabilitation: Department of Islamic Development Malaysia. Paper read at International Conference on Deradicalizationand Countering Violent Extremism 2016.

NST. (2016). "Malaysia's Counter-Messaging Centre combating terrorism, radical activities, says DPM." Retrieved on 11 July 2018, from https:/ /www.nst.com.my/news/2016/11/186976/malaysias-countermessaging-centre-combating-terrorism-radical-activities-says

NST. 2018. "DPM: Counter-Messaging Centre already fully operational." The New Straits Times. Retrieved on 16 June 2018, from https://www.nst.com.my/news/nation/2018/01/328337/dpm-countermessaging-centre-already-fully-operational

Qahthani, M.S. (2013). Al Wala' Wal Bara': Loyalitas dan Antiloyalistas dalam Islam. Translated by Salafuddin Abu Sayid. Solo, Indonesia, Pt Era Adicitra Intermedia.

Rabasa, A,, Stacie, L., Pettyjohn, J., Jeremy, G., and Boucek, C. (2010). "Southeast Asian Programs." In Deradicalizing Islamist Extremists. RAND Cooperation. 
Ramakrishna, K. (2016). "Reflections of a reformed jihadist: The story of Wan Min Wan Mat." Contemporary Southeast Asia, 38(3), 495-522.

Respondent A1. (2017). Ancaman radikal Islam di Malaysia. Interviewed by Siti Zubaidah Abu Bakar. Apr. 18.

Respondent A2. (2016). Ancaman Ekstremis Dan Radikal di Malaysia. Interviewed by Siti Zubaidah Abu Bakar. Oct, 10.

Samuel, T. K. (2016). Radicalisation in Southeast Asia: A selected case study of Daesh in Indonesia, Malaysia and The Philippines. Kuala Lumpur, SEARCCT.

Sariburaja, K. (2013). Al Jamaah Al Islamiyah. Malaysia, Southeast Asia Regional Centre for CounterTerrorism (SEARCCT), Ministry of Foreign Affairs.

Suffian Mansor. (2010). Kemunculan Kepimpinan Melayu Baru di Tanah Melayu Pada Awal Abad ke 20. In The 7th International Malaysia Studies Conference (MSC7).

Syaikh Ali Hasan, A.H. (2015). ISIS: Khilafah Islamiyah atau Khawarij. Translated by Lc Umar Mujtahid. Jakarta, Pustaka Imam Asy Syafi'i.

Wagemakers, J. (2012). A Quietist Jihadi: The Ideology And Influence of Abu Mubammad al Maqdisi. United Kingdom, Cambridge University Press.

Wan Abdul Hamid Wan Mahmud. (2006). Jaringan Jemaah Islamiyah di Malaysia dan keselamatan serantau, Master Thesis, Fakulti Sains Sosial dan Kemanusiaan, Universiti Kebangsaan Malaysia, Bangi.

Wan Mohd Zaki Wan Ismail. (2015). Politik dan keselamatan: Peranan PDRM menangani terorisme di Malaya dan Malaysia, Master Thesis, Fakulti Sains Sosial dan Kemanusiaan, Universiti Kebangsaan Malaysia, Bangi.

Zulkarnain Haron. (2014). Jaringan Al Jamaah Al Islamiyah di Asia Tenggara: Sejarah dan perkembangan (19502010), PhD Thesis, Fakulti Sains Sosial dan Kemanusiaan, Universiti Kebangsaan Malaysia, Bangi.

Zulkarnain Haron. (2017a). Al Dawla Al Islamiya Fi Iraq Wa Ash Sham (Daesh/ Daiish) a.k.a Islamic State in Iraq and Syria (ISIS). In Road Show Task Force Perisai Wira ATM, edited by Kementerian Pertahanan Malaysia. Institut Latihan dan Kefahaman Islam (ILIM) ATM.

Zulkarnain Haron. (2017b). Why counter-Terrorism Is Not Effective? Interviewed by Siti Zubaidah Abu Bakar, Oct. 10.

Zulkarnain Haron, \& Nordin Hussin. (2013). "A study of the salafi jihadist doctrine and the interpretation of jihad by Al Jamaah al Islamiyah." Kemanusiaan, 20(2), 15-37.

Zulkarnain Haron, \& Lailatul Afidzha Arif. (2016). "Corak terkini terorisme alaf baru (New terrorism)." Berita Tentera Darat Malaysia. 